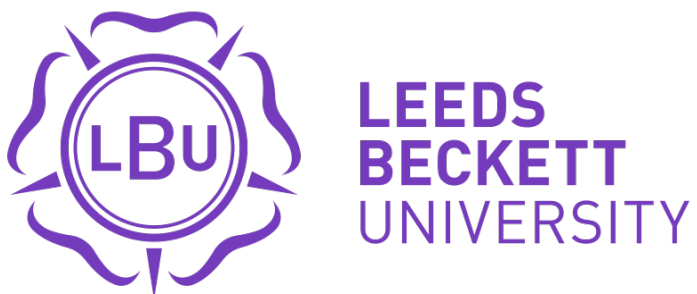

Citation:

Lee, MP (2019) Gaskell's Food Plots and the Biopolitics of the Industrial Novel. Victorian Literature and Culture, 47 (3). pp. 511-539. ISSN 1060-1503 DOI: https://doi.org/10.1017/S1060150318001596

Link to Leeds Beckett Repository record:

https://eprints.leedsbeckett.ac.uk/id/eprint/4865/

Document Version:

Article (Accepted Version)

(C) Cambridge University Press 2019

The aim of the Leeds Beckett Repository is to provide open access to our research, as required by funder policies and permitted by publishers and copyright law.

The Leeds Beckett repository holds a wide range of publications, each of which has been checked for copyright and the relevant embargo period has been applied by the Research Services team.

We operate on a standard take-down policy. If you are the author or publisher of an output and you would like it removed from the repository, please contact us and we will investigate on a case-by-case basis.

Each thesis in the repository has been cleared where necessary by the author for third party copyright. If you would like a thesis to be removed from the repository or believe there is an issue with copyright, please contact us on openaccess@leedsbeckett.ac.uk and we will investigate on a case-by-case basis. 
Author: Michael Parrish Lee

Article: Gaskell's Food Plots and The Biopolitics of the Industrial Novel

Journal: Victorian Literature and Culture

https://www.cambridge.org/core/journals/victorian-literature-and-culture

Accepted: 18 July 2017

Publisher: Cambridge University Press

Copyright: Open Access Options

\section{Gaskell's Food Plots and the Biopolitics of the Industrial Novel}

When is a pear not a pear? Near the beginning of Elizabeth Gaskell's North and South (1855), the novel's heroine Margaret Hale and her parents receive a visit from the family friend Henry Lennox. After their meal, Margaret's father Mr. Hale asks her to gather some pears from the garden for dessert and Henry suggests that they "adjourn into the garden, and eat them there." Margaret, Mr. Hale, and Henry go out to the garden where Margaret makes "a plate for the pears out of a beet-root leaf, which threw up their brown gold colour admirably." Henry, we learn, "looked more at [Margaret] than at the pears; but her father, inclined to cull fastidiously the very zest and perfection of the hour he had stolen from his anxiety, chose daintily the ripest fruit, and sat down on the garden bench to enjoy it at his leisure." While Margaret and Henry stroll through the garden alone, Henry proposes marriage and Margaret declines, and then the pears reappear:

It was well that, having made the round of the garden, they came suddenly upon Mr Hale, whose whereabouts had been quite forgotten by them. He had not yet finished the pear, which he had delicately peeled in one long strip of silver-paper

I would like to thank Caroline Herbert, Ned Schantz, Kate Thomas, and the editors of Victorian Literature and Culture.

${ }^{1}$ Gaskell, North and South, 29. Hereafter abbreviated NS and cited parenthetically by page number. 
thinness, and which he was enjoying in a deliberate manner. It was like the story of the eastern king, who dipped his head into a basin of water, at the magician's command, and ere he instantly took it out went through the experience of a lifetime. $(N S, 32)$

Mr. Hale's dessert encompasses an entire life that could be but isn't, a marriage that might come to pass but does not. Yet the shadowy counternarrative here is not really the marriage plot that doesn't occur but rather the "food plot" that even this unrealized marriage plot upstages. This sequence casts a spell no less impressive than the magician's in the story - making food, eating, and appetite conspicuously visible while at the same time making them seem devoid of any material importance. More than an instance of feeding, the meal becomes an occasion for hospitality and togetherness, a setting within which "conversation" flows "quietly and agreeably" $(N S, 28)$. Henry's proclamation that "Nothing is so delicious as to set one's teeth into the crisp, juicy fruit, warm and scented by the sun" $(N S, 29)$ might at first seem to mark a sensuous preference but quickly becomes transparent as a way of getting Margaret alone by moving the party outdoors. The artful plate of pears and beetroot leaf that Margaret arranges so effortlessly emerges as an aesthetic object only to reroute aesthetic interest away from itself, becoming an occasion to affirm that Henry is more interested in looking at Margaret than at food. And, in the end, even Mr. Hale's enjoyment of the pear seems to stand less as a pleasure in itself than to serve as a plot device keeping him busy while Margaret and Henry talk, an inconsequential event highlighting the greater interest of the courtship plot, and as a symptom of the "anxiety" that Mr. Hale needs distraction from (NS, 29). This scene's magic trick is to conjure food, eating, and appetite only to drain them of materiality and 
significance beyond the status as props and occasions for and distractions from other more ostensibly serious matters. A pear might bring a possible life into relief, but its status as something that can sustain life gets written out.

This choice to present food as a tool that shows rather than feeds life brings us to one of the key biopolitical problems that shapes the Victorian realist novel: the fact that the materiality of food and eating — particularly their connection to bodily appetiteseems to be forever vanishing from a form apparently devoted to representing life and lived experience. Such vanishing is especially peculiar when it occurs in a text such as North and South, since the "social problem" or "industrial" novel so explicitly takes up the struggles of the working poor. Few serious students of mid-nineteenth-century British culture could imagine that food, eating, and appetite were minor issues during a time that saw, for example, opposition to a New Poor Law often derided as the "Starvation Act," the Great Famine in Ireland, fierce debates over and the repeal of the Corn Laws, and, for that matter, a decade known as "the Hungry Forties" in which, as James Vernon points out, "a tidal wave" of newspaper reports detailed the plight of the hungry, "individuati[ng]" their suffering, and "demand[ing] attention and sympathy." ${ }^{2}$ Yet, until recently, food and eating have remained peripheral to studies of Victorian literature, and even notable work by scholars such as Annette Cozzi and Gwen Hyman tends to treat them more as indexes of other issues such as masculinity, class, and nationality, than as topics whose connection to material appetite bears exploration in its own right. ${ }^{3}$ In a

\footnotetext{
${ }^{2}$ Vernon, Hunger, 19.

${ }^{3}$ See Cozzi, Discourses of Food, and Hyman, Making a Man. Such literary treatments share what Jennifer L. Fleissner calls the tendency in the interdisciplinary field of "food studies" to try to "elevate eating," showing it as "something far more transcendent—and specifically human - than the satisfaction of a bestial hunger" ("Art of Eating," 29). Such
} 
sense, we might see such treatment as simply and appropriately following the lead of Victorian novels themselves in removing food and eating from mere appetite and necessity and turning them into intricate devices for revealing a complex and capacious social world.

I want to suggest, however, that this is only one side of the story of the Victorian novel's treatment of food. After all, the pear scene in North and South is part of the Hales' comfortable life in the south of England; it is that from which they depart, moving to the town of Milton-Northern (a fictionalized Manchester) in the industrial north, where some laborers are so hungry that they have come to rely on the cotton dust that gets into their lungs during millwork to make them feel full $(N S, 102-103)$. Appetite is there to see in Victorian novels but it emerges in ways that challenge familiar interpretive protocolswhether Margaret Hale's or our own — and requires a critical approach attentive to its disappearances as well as its appearances. Of course, Gaskell's move from an indexical treatment of food and eating to an emphasis on material appetite might itself appear mainly indexical, contrasting the lives of the southern gentry who are able to take eating for granted with those of the northern working classes who are not. Gaskell is certainly showing this contrast, but she is doing so in the process of working through a deeper

a tendency to transform, avoid, or downplay literal appetite is also prevalent more widely in cultural analysis, perhaps partly informed by the "antibiologism" that Eve Kosofsky Sedgwick and Adam Frank argue has underlain much theoretical work in the humanities since the early 1980s ("Shame," 114). For instance, in Practicing New Historicism Catherine Gallagher and Stephen Greenblatt perform a virtuosic analysis of the potato, a tuber whose "very significance as a particularly primitive food, a thing representing mere subsistence and (in some minds) the virtual end to culture" (111), provides "an opportunity to assert that representation knows no natural limits" (111-12). As this essay will make clear, I am interested in precisely those moments when novels imagine "mere" appetite and hunger as challenges, stumbling blocks, and even limit points for representation. 
ambivalence towards eating and appetite at the core of the novelistic framework that she is simultaneously writing within and modifying.

To help clarify Gaskell's achievement and the formal innovation of her industrial fiction, this essay develops and modifies an argument I have begun to make elsewhere: that the nineteenth-century marriage plot is structured against the materiality of eating. ${ }^{4}$ With the emergence of population as a key cultural concern and related Malthusian connections between sexuality and the food supply, the nineteenth-century British novel became shaped by the biopolitical interplay between the marriage plot and the "food plot" that constitutes those moments and sequences in which the materiality of food, eating, and appetite vies for narrative attention. Nineteenth-century British thought surrounding population was most crucially influenced by Thomas Robert Malthus, whose Essay on the Principle of Population (1798) puts forward two "postulata": "First, That food is necessary to the existence of man," and "Secondly, That the passion between the sexes is necessary, and will remain nearly in its present state."5 Malthus contends that these laws mean "the power of population is indefinitely greater than the power in the earth to produce subsistence for man." ${ }^{\circ 6}$ Malthusian thought, in other words, helped conceptualize population as something fundamentally excessive due to the prospect that food production could never keep up with unchecked reproduction. ${ }^{7}$ My contention is

\footnotetext{
${ }^{4}$ See especially my book, The Food Plot in the Nineteenth-Century British Novel.

${ }^{5}$ Malthus, Essay, 12.

${ }^{6}$ Malthus, Essay, 13.

${ }^{7}$ Even as it influenced the establishment of the modern census with its demographic project of taking account of the population, Malthusian thought thus lent itself from the start to a preoccupation with what Emily Steinlight calls "the uncountable mass of life that defies containment," marking "as a category that which exceeds categorization, rendering inclusion and exclusion equally impossible" ("Supernumeraries," 234). I argue,
} 
that the nineteenth-century British novel turned this problem into a formal tension between sexuality and appetite, between the marriage plot and the food plot. Whether haunted by this problem or grappling with it directly, ${ }^{8}$ nineteenth-century novelists who made the marriage plot central to their work treated appetite as a key site of formal excess, a disruptive remainder to the sexuality that the marriage plot requires.

The interplay between these two plots varies across the nineteenth century and from novel to novel, but it is generally tense and uneven, with the marriage plot the dominant partner (hence its survival in literary criticism) and the food plot behaving as a disruptive shadow narrative that is often subdued throughout through the text and expelled by the end of a novel. This interplay is a big part of why, for all of the meals that help structure Victorian narrative, appetite itself is often so elusive.

Industrial fiction presents a challenge to this dynamic. What happens to a novelistic form structurally dependent on the subordination of appetite when the hungry are brought into the center of narrative? This essay argues that Elizabeth Gaskell's industrial fiction reworks the prevalent relationship between the food plot and the marriage plot in a way that exposes its limits and elisions, not only giving appetite a central place in Victorian narrative but also drawing attention to the problematic ways in which marriage plots push appetite to the margins. My test case is Gaskell's first novel, Mary Barton (1848), which offers a view of the food plot that appears exemplary but proves itself exceptional. In its detailed exploration of working-class life, Mary Barton

however, that the nineteenth-century novel chiefly comes to terms with this excess through issues of food, eating, and appetite.

${ }^{8}$ On the powerful influence of Malthusian thought on the nineteenth-century literary imagination - including on the thinking of Malthus's most ardent detractors - see especially Catherine Gallagher's Body Economic. 
brings appetite and hunger out of the shadows as explicit topics of concern yet does so in ways that reenact the tension between the food plot and the marriage plot that subjects the materiality of eating to crucial disappearances. Such disappearances, as we will see, help make sense of Mary Barton's notoriously problematic form. Ultimately, though, Mary Barton's reenactment of the novelistic structure that subordinates appetite to romance self-consciously scrutinizes and finally destabilizes this structure. ${ }^{9}$

\section{Biopolitics and Novelistic Form}

Re-imagining the marriage plot as one partner in a biopolitical dance that includes the food plot necessarily complicates understandings of fiction informed by Ian Watt's alignment of the novel as a form with courtship, individualism, and private experience, and Nancy Armstrong's argument that "the discourse of sexuality is implicated in shaping the novel," enabling domestic fiction to help produce the modern individual—_a subject who understood herself in the psychological terms that had shaped fiction."10

\footnotetext{
${ }^{9}$ I have come to realize that the industrial novel constitutes a blind spot for my argument in The Food Plot. When the book touches on the industrial novel at the opening of Chapter 2 (44-47) it suggests that an industrial novel like Mary Barton treats food similarly to other novels of the period; the present article repudiates this. The book argues that nineteenth-century novelistic form contains a tension between the marriage plot and this food plot but that the food plot is usually the subordinate partner in the pair. This article, as will become clear, argues that Gaskell's industrial fiction draws on the more conventional novelistic framework but basically deconstructs it. Rather than working as a driving internal logic to Gaskell's industrial novels, the relationship between the food plot and the marriage plot is something that these novels actively explore, unsettle, and problematize, ultimately showing the conventional overinvestment in marriage and romance as a bad reading and writing habit that contributes to an underinvestment in food and appetite. Gaskell's work not only gives appetite a particularly prominent position (making the food plot a central plot instead of a shadow plot) but also troubles the novelistic union of romance and interiority over and above appetite that my book argues for.

${ }^{10}$ Watt, Rise of the Novel. Armstrong, Desire and Domestic Fiction, 31.
} 
Particularly influential in Victorianist circles, Armstrong's theory takes its most important cues from Watt and from Michel Foucault's account of "that great awakening of sexual concern since the eighteenth century" wherein the bourgeoisie "subordinated its soul to sex by conceiving of it as what constituted the soul's most secret and determinate part." ${ }^{11}$ I propose that the food plot reveals the flip side of the psychological subject generated by the marriage plot: a competing model of self driven by appetite rather than by desire and composed of gustatory insides rather than deep interiority.

I am hardly the first to challenge Armstrong's line of thinking, which has come under fire for its insistence that the marriage plot converts political relations into sexual relations and for the rather strict centralization of desire, sexuality, and individual subject formation that its Foucaultian bearings seem to dictate. Elsie B. Michie, for instance, argues that, far from producing a "domestic realm" safely "sealed off from the realm of the market," the "nineteenth-century marriage plot makes arguments that are as much about the social and political realms as they are about the private and personal realms usually associated with them." ${ }^{.2}$ And Talia Schaffer contends that novelistic marriage plots often "deemphasize sexuality in favor of other issues," not only "facilitat[ing] the development" of the kind of modern subject that Watt and Armstrong propose ("a liberal, autonomous, essential, rights-bearing citizen, with unique individuality and deep psychology"), but also envisioning "selfhood as relational, affective, and networked, governed by feelings and duties instead of rights and reasons." ${ }^{.13}$ Thanks to such work, the nineteenth-century marriage plot now seems more dynamic and capacious than it

\footnotetext{
${ }^{11}$ Foucault, History of Sexuality, 151, 124. Hereafter abbreviated $H S$ and cited parenthetically by page number.

${ }^{12}$ Michie, Vulgar Question, 18.

${ }^{13}$ Schaffer, Romance's Rival, 23.
} 
once did. No longer a cramped space of discipline and confinement upholstered to resemble freedom, the marriage plot now appears as a flexible, self-reflexive form capable of incorporating politics and economics, accommodating companionship and sociability along with sexual desire, and producing multivalent subjects whose depths extend outward as well as inward. More than accounts of the marriage plot as a coercive ideological instrument, this renewed sense of the form's pliability and scope as a tool for understanding the social helps to clarify why it had such a massive appeal for nineteenthcentury novelists.

On the surface, then, such revisions to our understanding of the marriage plot might entail that we turn away from Foucault as well as from Armstrong. But a reading of Foucault that would give us a self-enclosed individual driven by erotic desire alone misses out on how his thinking on biopolitics might complicate such an idea. Foucault links the eighteenth-century "awakening of sexual concern" to the "emergence of 'population' as an economic and political problem” $(H S, 25)$. This emergence meant more than the production of a sexualized individual subject; it gave rise to "a bio-politics of the population" that "focused on the species body, the body imbued with the mechanisms of life and serving as the basis of the biological processes: propagation, births and mortality, the level of health, life expectancy and longevity, with all the conditions that can cause these to vary" $(H S, 139)$. As Emily Steinlight argues, the rise of biopolitics meant that by the nineteenth century, "Life itself, and the means by which it is preserved or expended, ha[d] become more elemental to the ideological work of the novel than any other object, telos, or metric." 14 Not simply an instrument of biopolitical power,

${ }^{14}$ Steinlight, "Supernumeraries," 232. 
nineteenth-century fiction works to contemplate and navigate the emerging biopolitical field in ways that fundamentally shape novelistic form and help explain its reliance on the marriage plot.

For Foucault, "the extreme emphasis placed upon sexuality in the nineteenth century" is due to "the privileged position it occupies between organism and population, between the body and general phenomenon." 15 In this light, sexuality in the nineteenthcentury novel functions neither as an ideological curtain concealing politics nor as a mere cipher for other social issues, but instead as a key meeting point of politics and economics with biological "life itself" $(H S, 143)$ through which the social is conceived of in terms of a population. And the Victorian marriage plot, I suggest, is less crucially committed to manufacturing and disciplining a sexually desiring individual than to working through a vision of the social structured around reproductive futurity where the life of the protagonist, in all its social, political, and psychological complexity, moves towards a union that offers the promise of regenerating the life of the population. ${ }^{16}$ Even when Victorian marriage plots seem to deemphasize sexuality or present it as something in need of regulation, most position it formally as the possibility, if not the inevitability, that narrative moves towards.

\footnotetext{
${ }^{15}$ Foucault, "Society Must Be Defended”, 252.

16 This is why Caroline Levine is right to criticize how "we regularly call the formal phenomenon of a novel's ending its closure," since "what the novel imagines in its conclusion is really not an enclosure at all, but a beginning - the launching of a series of social and political relationships" that promise to "endure beyond the narrative's end" in an implicit "future" that is "a deliberately uncontained temporal process" (Forms, 41). See also Aaron Matz, who argues that the nineteenth-century marriage plot is usually also a "procreation plot" ("Procreation," 23), and Lee Edelman, who theorizes that "reproductive futurism" is the "limit and horizon" of the "political field" (No Future, 27).
} 
But marriage and sexuality only make up part of the picture when considering the biopolitics of the nineteenth-century novel. In Britain, it was Malthus who most influentially shaped the concern with population and, as we have seen, for Malthus, sexuality was inextricably and problematically linked to the issue of the food supply. As appetite became the Malthusian shadow of desire, sexuality, and procreation, the everreturning need to eat manifested in novelistic food plots that threatened to destabilize the futurity of the marriage plot. Through the interplay between these plots, novelistic form itself became biopolitical. In its project of giving "utterance to the agony which from time to time convulses" marginalized working-class sectors of the population disproportionately exposed to "want," 17 Elizabeth Gaskell's industrial fiction participates in but reshapes this interplay, attempting to turn the food plot from a disruptive shadow narrative into the novel form's epicenter and central problematic.

\section{Eating and Aesthetics}

Why should the Victorian novel more than other cultural forms bear such an ambivalent relation to eating and appetite? While this ambivalence owes much to the rise of Malthusian population theory, it was also influenced by earlier developments in the field of aesthetics. As Carolyn Korsmeyer puts it, this field "emerges in eighteenthcentury European philosophy" as a "distinctive approach to perception, pleasure, beauty" that "make[s] central the notion of Taste, conceived as a sensitivity to fine distinctions and an ability to discern beauty." 18 But while gustatory taste "provides the language,

${ }^{17}$ Gaskell, Mary Barton, 5. Hereafter abbreviated $M B$ and cited parenthetically by page number.

${ }^{18}$ Korsmeyer, Making Sense of Taste, 40. 
indeed the conceptual framework" for aesthetic Taste, Korsmeyer argues, "within most theories aesthetic Taste seeks to attain the detachment and contemplative distance of vision, leaving the literal sense that provides the metaphor behind." ${ }^{19}$ One of the most important theorists of Taste, Immanuel Kant subordinates alimentary taste even in describing the ideal "tasteful" dinner party:

When I manage a dinner party composed of nothing but men of taste (aesthetically united), in so far as they intend not merely to have a meal in common but to enjoy one another's company (this is why their number cannot amount to many more than the number of graces), this little dinner party must have the purpose not only of physical satisfaction - which each guest can have by himself alone - but also social enjoyment, for which physical enjoyment must seem to be only the vehicle. ${ }^{20}$

Denise Gigante and Peter Melville point out that, in Kant's words, food is only a "vehicle" for social life. ${ }^{21}$ Moreover, Kant aligns aesthetic Taste with the social as such and structures this alignment upon and against physical appetite. Such aesthetic subordination of the alimentary was crucial to the intersection of the British novel with the project of Taste that Deidre Shauna Lynch describes emerging at the turn of the nineteenth century in new practices of reading and writing character that emphasize depth and complexity. ${ }^{22}$ If, after Georg Lukács's Theory of the Novel (1971), "interiority" is a

${ }^{19}$ Korsmeyer, Making Sense of Taste, 38, 39. See also Pierre Bourdieu, who argues that an opposition between the "taste of sense" and the "taste of reflection" has "been the basis of high aesthetics since Kant" (Distinction, 6).

${ }^{20}$ Kant, Anthropology, 179.

${ }^{21}$ Gigante, Taste, 8-9. Melville, Romantic Hospitality, 67.

${ }^{22}$ Lynch, Economy of Character. While Lynch sees such emphasis as a practice of distinction principally related to the rise of market culture, I would suggest that this new 
name often given to such depth, ${ }^{23}$ then we might say that the nineteenth-century British novel constructs the interiority of deep character against the counter-interior of bodily appetite. $^{24}$

The Victorian novel draws on this aesthetic model that marginalizes appetite and complicates this model with the Malthusian tension between sexuality and the food supply, a tension that generates competing impulses in fiction to represent appetite and to write it out. In the nineteenth-century novel, appetite vacillates between dullness and powerful excess, constituting that which deep interiority, the marriage plot, and the novelistic social itself are structured against while threatening to become that which might replace them, even if the food plot is usually expelled by the end of a given novel. However, while this narrative and aesthetic model dominated Victorian fiction, Elizabeth Gaskell's industrial novels worked to show that appetite never really goes away.

\section{Mary Barton and the Food Plot}

What happens to the food plot when we turn to a novel that treats appetite not as something interrupting the marriage plot but as a central problem in itself? Despite the fact that Victorian industrial fiction is often so explicit in dealing with hunger, academic studies of the subject have tended to skirt around specific problems of food, eating, and

way of understanding character is also bound up, more ambivalently, with the biopolitical concern with population that it emerges alongside. Seeing a character in terms of unknowable depths seems part of a double move that at once aims to create distinction from a vast population and to incorporate and work though some of this vastness within the space of the individual character. As with the population, there is always potentially more "life" within the individual character whose depths can never fully be grasped.

${ }^{23}$ Lukács, Theory of the Novel, 89.

${ }^{24}$ For more detail on how this dynamic works within nineteenth-century fiction, see Lee, "The Nothing in the Novel" and Food Plot, especially 1-16. 
appetite in a way that seems disproportionate to the fiction's overt concerns and contemporary responses to it. Even the rare scholarly work that does engage with these problems in sustained ways tends to treat food and eating in an indexical manner. ${ }^{25}$ Compare, for instance, Josephine M. Guy's insight in The Victorian Social-Problem Novel (1996) that "the nature of the specific meals" in Mary Barton "is an index both of the moral character of the giver and of the strength of community between giver and receiver" with the words of Charles Kingsley in his 1849 review of Gaskell's novel: Do [readers] want to get a detailed insight into the whole "science of starving,""clemming," as the poor Manchester men call it? Why people "clem," and how much they can "clem" on; what people look like while they are "clemming" to death, and what they look like after they are "clemmed" to death and in what sort of places they lie while they are "clemming," and who looks after them, and who - oh, shame unspeakable! - do not look after them while they are "clemming;" and what they feel while they are "clemming;" and what they feel while they see their wives and their little ones "clemming" to death round them; and what they feel, and must feel, unless they are more or less than men, after all are

\footnotetext{
${ }^{25}$ For notable exceptions, see Tamara Ketabgian, who hones in on the importance of "appetites" to "Gaskell and her peers" but bundles together multiple modes of appetite, "whether for food, alcohol, drugs, or dress" (Lives of Machines, 72), and Lesa Scholl, whose analysis is attentive to hunger but often slips between literal and metaphoric hunger in ways that sometimes risk effacing the specificity of bodily appetite in Gaskell's work; for instance, she writes that "Mary [Barton] is consumed by her hunger for more: for food; for stability; and most importantly for a way to move out of her desperate situation" (Hunger Movements, 107). See also Elaine Freedgood, who, observing that characters in Mary Barton "hunger, starve, and die at an alarming pace," suggests that the Irish Famine "haunts Mary Barton" (Ideas in Things, 65).
} 
"clemmed;" and gone, and buried safe out of sight, never to hunger, and wail, and pine, and pray for death any more for ever? Let them read Mary Barton. ${ }^{26}$

Guy's sensitivity to the social nuances of eating and its potential implications for thinking through wider economic issues opens up worthwhile avenues for understanding the text but says little about the physical and affective dimensions, or the bodily experience and consequences, of hunger that Kingsley is so concerned with. Gaskell's novel certainly invites many opportunities for indexical readings of food and eating, yet it also troubles such moments by bringing hunger front and center as something that powerfully breaks down familiar modes of signification while calling for new ones. Mary Barton gives us a situation in which

$[\mathrm{t}] \mathrm{h}[\mathrm{e}]$ disparity between the amount of the earnings of the working classes and the price of their food, occasioned, in more cases than could well be imagined, disease and death. Whole families went through a gradual starvation. They only wanted a Dante to record their sufferings. And yet even his words would fall short of the awful truth; they could only present an outline of the tremendous facts of the destitution that surrounded thousands upon thousands in the terrible years 1839,1840 , and 1841. $(M B, 76)$

Hunger here is depicted as partly unwritable, having a troubling power that overwhelms language. Such power reveals itself both as a problem of sensation or experience, where the suffering cannot be sufficiently documented, and one of population, where the sheer number of cases cannot be imagined. Hunger here stands as the excess that brings into

${ }^{26}$ Guy, Social-Problem Novel, 155. Kingsley, Review of Mary Barton, 381-82. 
view the meeting point of the novel's democratic and demographic drives as well as the limitations of such drives. Gaskell demonstrates the wish to take account of people and bring their experiences to light while asserting that hunger marks and exceeds the threshold of such bearing witness as an untellable experience lived by an uncountable number of people.

Gaskell also makes it clear that the representability of hunger is a political as well as an artistic and linguistic problem:

[T]he starving multitudes had heard, that the very existence of their distress had been denied in Parliament; and though they felt this strange and inexplicable, yet the idea that their misery had still to be revealed in all its depths, and that then some remedy would be found, soothed their aching hearts, and kept down their rising fury. $(M B, 77-78)$

The novel depicts hunger and the problem of making hunger known as the wellspring of the Chartist movement: "So a petition was framed, and signed by thousands in the bright spring days of 1839 , imploring Parliament to hear witnesses who could testify to the unparalleled destitution of the manufacturing districts" $(M B, 78)$. One of the "hungerstamped" delegates appointed "to convey this petition, who might speak, not merely of what they had seen, and had heard, but from what they had borne and suffered" is John Barton, the central character of the first part of the novel whose participation in Chartism and trade unions ultimately facilitates his perpetration of the murder that stands as the novel's key event. The sufferers of hunger hope to inscribe fully their condition ("in all its depths") into public politics — an inscription that would entail the difficult task of making language convey the visual, auditory, visceral, and affective dimensions of 
hunger and its consequences, enacting what Jacques Rancière calls "a new distribution of the perceptible." ${ }^{27}$ But while the text is clear that such hunger should be communicated, it also suggests the ultimate futility of this political mission through its previous positioning of hunger as finally incommunicable. And as with the actual 1839 refusal of Parliament to hear the Chartist petitioners, John Barton and his fellow Chartists are not granted their audience with Parliament. By pairing artistic-linguistic failure (via Dante) with political failure, Gaskell's novel sets itself up as a space where art and politics not only converge but do so in their inability to deal with hunger. The novel thus imagines itself as a space of representational failure but also as one that has the added capacity of acknowledging and reflecting on this failure. In this way, the very incommunicability of hunger seems to contribute to the urgency of trying to grasp or communicate it. Hunger in Mary Barton stands at the threshold of politics, artistic representation, and novelistic form as excess, impossibility, and driving force.

This brings us to one of the paradoxes of the food plot: despite its power, appetite is often positioned as somehow both inside and outside of what a novel marks out as its narrative, working similarly to the "bare life" that Giorgio Agamben sees as at once both inside and outside the political order, occupying a place of "exclusion (which is simultaneously an inclusion)." ${ }^{28}$ It is as though the novelist's wish to narrate appetite were bound up with a competing need to free narrative from appetite. Near the beginning of Mary Barton, for example, there is a lengthy food preparation sequence that morphs into an all too short eating scene. We begin with a relatively static description of the inside of the Bartons' home featuring "plates and dishes" and "knives and forks"; soon

${ }^{27}$ Rancière, Politics of Literature, 13.

${ }^{28}$ Agamben, Homo Sacer, 7. 
"the merry clatter of cups and saucers" animates this description $(M B, 16)$ before Mary is sent out for provisions for entertaining the Wilsons and returns home to cook ham and eggs, and the house fills with "the savoury smells, the comfortable sounds of a boiling kettle, and the hissing frizzling ham" $(M B, 18)$. This sequence illustrates many things, including the Bartons' "hospitality" $(M B, 16)$ and relative prosperity at this point in the novel, their relationship with the Wilsons, and the young Mary's "confidence" $(M B, 19)$ and "fond[ness]" for "power" $(M B, 18)$. Food, cutlery, and cooking, in other words, lend themselves to indexical readings here, but the Bartons' meal itself is less easily reconcilable with such familiar reading habits: "At length the business actually began. Knives and forks, cups and saucers made a noise, but human voices were still, for human beings were hungry and had no time to speak" $(M B, 19)$. Eating and appetite take on an immediacy at odds with the narrative unfolding of the novelistic social. Eating becomes "the business" itself - that which occupies the "actual" that is prepared for "[a]t length" and then quickly dispersed. Here, even mild, everyday appetite has the power to stop speech, the mouth no longer communicating or projecting outward, but taking food inward. ${ }^{29}$ This voiceless intake only lasts for a brief moment of reading time and becomes a kind of black hole sucking in narrative and deep character: preparation becoming the thing itself, human insides ceasing to function as vessels of interiority and becoming instead alimentary canals, characters put on uncomfortably even footing with the objects that surround them.

${ }^{29}$ In The Hunger Artists, Maud Ellmann compellingly suggests that, "the fact that language issues from the same orifice in which nutrition is imbibed means that words and food are locked in an eternal rivalry" (46). 
Yet this moment in which the noise of tableware overtakes human speech soon gives way again to voice and interiority:

Alice first broke silence; holding her tea-cup with the manner of one proposing a toast, she said, "Here's to absent friends. Friends may meet, but mountains never."

It was an unlucky toast or sentiment, as she instantly felt. Everyone thought of Esther, the absent Esther; and Mrs. Barton put down her food, and could not hide the fast-dropping tears. Alice could have bitten her tongue out. $(M B, 19)$

Esther is Mrs. Barton's missing sister, and it will turn out that her absence involves a narrative of betrayed love leading to a life of prostitution. The food plot of mute appetite and noisy objects, then, gives way to the emotional turbulence that attends a romance plot gone wrong. Food is put down so tears can flow, and the tongue ceases to be a tasting organ as it becomes an instrument of misdirected speech. The dinner, so laboriously prepared for, now disappears into a ruined evening, and this plays out on a micro-level how a romance plot can turn aside a food plot to assert itself as a novel's "real" narrative and proper carrier of emotional power.

A similar dynamic also plays out at a larger structural level. The early part of the novel focuses on Mary's father, John Barton, whose economic and political struggles center on the hungry body and the problem of food provision. His back story, we learn, is one of fatal family malnutrition wherein "[h]is parents suffered; his mother died from absolute want of the necessaries of life" $(M B, 24)$. And when John is out of work due to a "depression of trade," his son Tom, "the apple of his eye, the cynosure of all his strong 
power of love" falls ill and his recovery "depend[s] on good nourishment" $(M B, 24)$ but the Barton household is running out of food and John's credit is "worn out at the little provision shops" $(M B, 25)$. In this failing struggle for food, John vividly experiences the "contrast" between rich and poor $(M B, 24)$ in a way that shapes his political sensibilities and generates his anger towards the employers:

Hungry himself, almost to an animal pitch of ravenousness, but with the bodily pain swallowed up in anxiety for his little sinking lad, he stood at one of the shop windows where all luxuries are displayed; haunches of venison, Stilton cheeses, moulds of jelly — all appetising sights to the common passer-by. And out of this shop came [his former employer's wife] Mrs. Hunter! She crossed to her carriage, followed by the shopman loaded with purchases for a party. The door was quickly slammed to, and she drove away; and Barton returned home with a bitter spirit of wrath in his heart, to see his only boy a corpse!

You can fancy, now, the hoards of vengeance in his heart against the employers. $(M B, 25)^{30}$

As with the earlier eating scene in the Bartons' house, appetite takes on the power to make subjects and objects somewhat interchangeable, but here this power is amplified to horrific effect. In his hunger, John Barton witnesses a vista of edible objects that he cannot access only to return home to his son, who, deprived of nutrition, is now an inanimate body. This is part of why food so often works differently from other objects in fiction: it is the type of object that most vividly exposes the precariousness of people's distinction from objects. Appetite thus takes fiction in a direction very different from the

${ }^{30}$ See also my reading of this passage in Lee, Food Plot, 44-45. 
marriage plot where subjects enter into contracts with one another (however unevenly), veering closer to Sandra Macpherson's vision of novelistic characters as "matter in motion"31—although, without food to fuel it, human matter stops dead in its tracks, revealing itself as a cadaver in waiting. John Barton's dead child brings us face to face with the food plot as the negativity threatening to undo the reproductive futurity that the Victorian novel promises.

But this is not the direction that this or almost any other Victorian novel finally takes us. The text reveals the child's death as producing the violent feelings towards the employers that will set the stage for John's later murder of the industrialist's son, Harry Carson, and we learn that the death is also a key cause of the engagement in politics that will directly lead John to commit the murder. However, the same sentence that would solidify the food plot's power and centrality also points away to the romance plot involving John's daughter Mary: "So while Mary took her own way, growing more spirited every day, and growing in her beauty too, her father was chairman at many a Trades' Union meeting; a friend of delegates, and ambitious of being a delegate himself; a Chartist, and ready to do any thing for his order" $(M B, 25)$. Mary, who determines "that her beauty should make her a lady" $(M B, 26)$, enters into a flirtation with the wealthy Harry Carson before realizing her love for her eventual husband, Jem Wilson. After Harry's murder, the narrative shifts its focus from John to Mary, who at first believes Jem to be the killer because of an altercation between Jem and Harry over the latter's flirtation with Mary that leads to Jem's arrest and trial for the murder. In the second half of the novel, Mary, who learns of her father's guilt, tries to exonerate Jem without incriminating

\footnotetext{
${ }^{31}$ Macpherson, Harm's Way, 15.
} 
her father. While it is clear that hunger and its effects are what make the killing possible, ${ }^{32}$ this food plot is kept in the shadows while the romance plot is made public and, in a sense, put on trial, as Mary takes the witness stand and, in a testimony that Jonathan H. Grossman calls "the centerpiece of the trial scene and the novel," 33 must divulge her "heart's secrets" regarding her "favoured lover" and publicly reveal her love for Jem $(M B, 281)$. Eventually Jem is exonerated and he and Mary are wed.

In some respects, this shift in focus from an unusually sustained and intense food plot to a romance plot helps account for the formal difficulties that Mary Barton poses for so many readers. Critics have long found the novel formally disjunctive or eccentric, particularly due to the narrative's shift in focus from John to Mary Barton and her navigation of the romance plot. Most influentially, Raymond Williams writes of the shift from the novel's early chapters, which for him constitute "the most moving response in literature to the industrial suffering of the 1840s," to "the familiar and orthodox plot of the Victorian novel of sentiment." ${ }^{34}$ But while Mary Barton would thus seem a textbook case of the ideological conversion of social and political relations into domestic and sexual relations that Nancy Armstrong sees at work in novelistic romance plots, subsequent readers of Gaskell have attempted to rescue Mary Barton for politics. For example, Hilary M. Schor argues that " $[\mathrm{t}]$ he same political critique that marks the 'John Barton' plot informs Mary Barton's plot"; Deborah Epstein Nord writes that "the sexual plot is at all points inseparable from the plot of class antagonism"; and Chris R. Vanden

\footnotetext{
${ }^{32}$ Lisa Surridge and Thomas Recchio have produced particularly convincing accounts of the role that the death of John Barton's son plays in John's killing of Harry Carson. See Surridge, "Working-Class Masculinities," especially 337, and Recchio, "Melodrama," especially 299, 302.

${ }^{33}$ Grossman, Art of Alibi, 121.

${ }^{34}$ Williams, Culture and Society, 87, 89.
} 
Bossche holds that "the romance plot does not displace but rather allegorizes the social plot." 35 Such readings acknowledge the multiplicity of the two plots while also seeking to reconnect them, suggesting that the shift from John to Mary is not really disjunctive because narratives of romance and sexuality are political, or at least can relay political meaning. My sense, though, is that the question of romance versus politics in Mary Barton is something of a false start. As these and other critics have shown, there is no real shift away from the political; however, there is a shift in where political and narrative attention chiefly resides - moving from the issues surrounding food access and hunger that dominate John's plot to the issues surrounding love, sexuality, and marriage that dominate Mary's.

This movement is far from straightforward and works on multiple levels. On one level, the general shift from the food plot to the marriage plot could be read as promoting a model of deep selfhood and futurity that privileges choice, desire, sexuality, and feeling over bodily appetite and necessity. But on another level, even as Gaskell works with this model, she complicates and scrutinizes it, not simply producing but self-consciously presenting the tension between the food plot and the romance plot, and ultimately putting pressure on the narrative privilege of the latter. This is why criticism that attempts to repair or iron out the friction between Mary Barton's two plots risks missing the biopolitical work that such friction achieves. Chapter 6 , for instance, tells the story of the Davenports, hunger-stricken during a stretch of unemployment due to a temporary closure of the Carsons' mill. John Barton and Jem's father, George Wilson attempt to provide relief to the family — the mass-like "cluste[r]" of children $(M B, 55)$

${ }^{35}$ Schor, Scheherazade, 14. Nord, Walking, 150. Vanden Bossche, Reform Acts, 165. 
"clamour[ing]" for bread, the mother "past hunger" $(M B, 56)$, the father a "worn skeleton of a body" driven by "animal instinct" $(M B, 57)$. As John stays with the family, Wilson travels to the Carsons' house to "beg for an Infirmary order" $(M B, 61)$. Here he encounters "mixed and appetising" cooking "odours" that make him "yearn for food to break his fast" $(M B, 61)$. As he discusses the order with Mr. Carson, the son, Harry, "finish[es] his breakfast" and gives Wilson five shillings for the "poor fellow," and goes "past quickly" $(M B, 64)$ as he is "anxious to be in time to have a look and a smile from lovely Mary Barton, as she went to [her employer's] Miss Simmonds"” (MB, 64-65). Here Gaskell pries apart the nineteenth-century novelistic pairing of deep interiority and romance. Despite Harry's charity, his thoughts of romance in the midst of all the hungergenerated suffering presented pages earlier appear one-dimensional and tangential to the narrative being built, and the effect is that he seems to occupy a flat and delimited “character-space," to use Alex Woloch's term. ${ }^{36}$ In contrast, Wilson's thoughts of food further connect him to the nearly-starving Davenports who also occupy his mind and show him as part of a complex network of people who cannot afford not to think about food, including the Carsons' cook, who, "when she had had time to think, after breakfast was sent in, had noticed [Wilson's] paleness, had had meat and bread ready to put in his hand when he came out of the parlour" $(M B, 65)$. Here, having food and eating on one's mind is a sign of multivalent consciousness where romantic desire marks psychological contraction.

It is not only Harry, the "bad" shallow lover whose thoughts of romance appear flat when contrasted with a food plot. Immediately before the description of widespread

\footnotetext{
${ }^{36}$ Woloch, One vs. the Many, 13.
} 
hunger giving rise to Chartism that I examined earlier, Jem Wilson goes to the Barton house looking for Mary but finds only John. We read that Jem "gave up hope of seeing Mary again by her own good free will; and the next best thing would be, to be alone to think of her. So muttering something which he meant to serve as an excuse for his sudden departure, he hastily wished John good afternoon, and left him to resume his pipe and his politics" $(M B, 76)$. The would-be deep interiority involved in being alone with one's thoughts of love looks like a regressive retreat from the social when juxtaposed with the disclosure of the contents of John's "politics" that follows: the indescribable suffering and hunger of a vast population and the large-scale actions motivated by such suffering. Jem's solitary romantic thoughts cannot but seem flat next to the unspeakable, politically mobilizing hunger of an uncountable population.

Yet the narrative shift to Mary's story appears to enact a biopolitical move that reframes the terms through which life matters. As the chief focus of the story becomes Mary's efforts to exonerate Jem, the novel seems to abandon its commitment to the lives of the starving multitudes that include John Barton and invest disproportionate value in the "precious life" of the romantic beloved $(M B, 203)$. Such abandonment, however, is complexly bound up with the care for life. ${ }^{37}$ Far from unconnected to the novel's early concerns, the shift from the food plot to the marriage plot constitutes an attempt to regenerate working-class life by envisioning a reproductive future for it that is unfettered from hunger - an effort (however insufficient) to imagine a way out of the Malthusian

\footnotetext{
${ }^{37}$ Arne De Boever suggests that the novel as a form is "a work of bioart that is traversed by both biopolitical concerns and by concerns with the care for the self and the care for others" (Narrative Care, 13). But while, for De Boever, "the novel could be read as a site where care's imagination exists in a perpetual struggle with the novel's biopolitical origins," my sense is that, in the nineteenth-century British novel, biopolitical concerns and care - as strange bedfellows as two terms might seem - are fundamentally connected.
} 
problematic where procreation multiplies appetite. Gaskell, moreover, interrogates this move even as she makes it. Throughout Mary Barton, Gaskell self-consciously presents the tension between the food plot and the marriage plot rather than simply enacts it. Gaskell displays this tension overtly when, for example, Mary's aunt Esther shows her a piece of paper that she has discovered in a hedge next to the location of Harry Carson's murder. Esther believes the paper was "used as wadding for the gun" that killed Harry due to "the shape it's crammed into" $(M B, 210)$. She also believes the paper points to Jem as the killer because it has Mary's name on it. But after Esther leaves Mary alone we learn that Mary has realized that the paper points instead to her father's guilt. She recognizes the paper as a piece torn from a valentine given to her by Jem- - in those days when she did not treasure and hoard up everything he had touched, as she would do now" $(M B, 213)$ - on which she had subsequently copied lines by the working-class poet Samuel Bamford and then given to her father. The paper is a dense palimpsest of romance plots and food plots: at once a valentine and a poem about the "famished" poor $(M B, 100)$, and serving as evidence first of a murderous lover and then of a killing set in motion by the consequences of hunger. Through Gaskell's explicit presentation of the paper in terms of text that is subject to multiple writers, multiple readings, and misreading, she draws attention to the very problem of competing plots that scholars have criticized her for or sought to repair. The fact that the romantic reading of the paper turns out to be the misreading even as the plot of Mary Barton seems increasingly motivated by Mary's love for Jem suggests the novel performing a critique of the marriage plot form that it appears to adopt. Similarly, the fact that John Barton's food plot is given as the real cause of the murder but kept secret and consigned to the shadows while Mary's 
romance plot is tried in public suggests less a straightforward triumph of the marriage plot than Gaskell subjecting novelistic form itself to trial-like scrutiny.

Gaskell's interrogation of the marriage plot, however, doesn't simply undermine this form but ultimately exposes how it shares its underpinnings with the food plot. Crucial here is Mary Barton and her position as simultaneously caught between and privy to both versions of the murder. This position marks her less as an emblem of the romance plot that replaces her father's food plot than as the key mediator of these plots, revealing the tensions as well as the connections between them. ${ }^{38}$ For example, while Mary is still infatuated with Harry Carson, she learns of Mr. Davenport's death, and we read that she “forgot all purposed meeting with her gay lover, Harry Carson; forgot Miss Simmonds' errands, and her anger, in the anxious desire to comfort the poor lone woman" $(M B, 66)$. The comforting words that Mary utters point to a nexus between marriage plots and food plots: “Oh, don’t cry so, dear Mrs. Davenport, pray don't take on so. Sure he's gone where he'll never know care again. Yes, I know how lonesome you must feel; but think of your children. Oh! we'll all help to earn food for 'em" $(M B, 66)$. Mary at once acknowledges the emotional bond of the conjugal couple and emphasizes that marriage is also an economic union involved in the material work of providing sustenance for the children that are the products of this union. Instead of simply leading the novel in the direction of romance, then, Mary is the figure through which marriage plotting converges

\footnotetext{
${ }^{38}$ While she does not read Mary Barton in this way, Schor's explorations Gaskell's use of character-mediators in Cranford (1851-53) and North and South have informed my thinking. Schor reads Cranford's Mary Smith as "mediat[ing]" between "the Cranfordians, living and dead, and their non-Cranfordian readers" (Scheherazade, 110) and Margaret Hale in North and South as a "mediatrix": "as a kind of interpreter among and between the many different discourses of industrialization" (121).
} 
with questions of the food supply and through which any final separation between the marriage plot and the food plot becomes untenable.

We see such convergence again a few pages later when Mary's dreams reveal her romantic interest in Harry Carson to be tangled up with food plots. She dreams of "the day when she should ride from church in her carriage, with wedding-bells ringing, and take up her astonished father, and drive away from the old dim work-a-day court for ever, to live in a grand house, where her father should have newspapers, and pamphlets, and pipes, and meat dinners, every day, - and all day long if he liked" $(M B, 73) .{ }^{39}$ "Such thoughts," we learn, "mingled in her predilection for the handsome young Mr. Carson." While, as Susan Zlotnick notes, "Gaskell makes clear that Mary regards her wealthy lover with the shrewd, appraising eye of a woman who understands the socioeconomic realities of the world," 40 when Mary later "discover[s] the passionate secret of her soul" $(M B, 117)$ - that she "love[s] Jem above all persons or things"—-she dismisses such earlier fantasies as "hollow vanities." Carolyn Lesjak suggests that, with Mary’s realization that she loves Jem rather than Harry, "the intimate link between desire and economics is rendered "fanciful.",41 But I think the text is more ambivalent about Mary relinquishing such economic fancies, especially if we don't just see her dream as about the economic as such but as moving through the economic more generally to arrive most crucially at bodily appetite. The dream begins with marriage, moves through a number of economic benefits that the marriage would allow (a large house, leisure time, pipes), but

\footnotetext{
39 The limitless supply of meat for John Barton in Mary's fantasy gains its specific appeal not only as a food supply and a sign of plenty but also through the fact that, as Chris Otter puts it, "Meat-eating, national vitality, status and masculinity have, of course, been synonymous, in Britain and elsewhere, for centuries" ("Vital City," 526).

${ }^{40}$ Zlotnick, Women, 81.

${ }^{41}$ Lesjak, Working Fictions, 40.
} 
also points to Chartist politics in John Barton's reading materials, before coming to the prospect of an endless feast. Marriage and eating form the two poles of Mary's dream, and here we glimpse an alternate resolution to that of the conventional novelistic marriage plot: the ongoing satisfaction of bodily appetite. Lesa Scholl points out that Mary's fantasy moves “in a direction away from self-interest, and reminds the reader, through the mention of meat dinners for her father, that this desire comes from the very real poverty that Mary experiences in such close proximity to the attractive luxury of the Carsons." 42 Indeed, within the narrative context of Mary's dream, shortly after the Davenport story, the food elements the dream belong less to a fantasy of upward mobility than to the bodily sufferings of those around her and are more socially engaged and complex (and much more attuned to the central problems of the first part of the novel) than Jem's desire for her or her love for Jem.

Once Mary realizes her feelings for Jem she experiences a version of love ostensibly free from connections to economics and bodily necessity. This is not, however, a simple ideological retreat into a contracted realm of private domestic feeling. Through the shift in focus to Mary and her love plot, Gaskell enacts the double-edged move of abandoning the food plot for the marriage plot of reproductive futurity while subjecting this abandonment to critical scrutiny. After Harry's murder, while Mary still thinks Jem is guilty, she encounters an Italian child begging, "Hungry! so hungry" and "point[ing] to his mouth, with its white quivering lips" $(M B, 202)$. In her distressed state, Mary “impatiently" answers, "Oh, lad, hunger is nothing—nothing!" and "rapidly pass[es] on." Mary Poovey argues that, by this point in the novel, "Gaskell has all but discounted

${ }^{42}$ Scholl, Hunger Movements, 168-69. 
poverty as a source of meaningful distress, which is now figured as emotional pain," and that "what takes the place of physical suffering is mental distress." ${ }^{43}$ But the idea that hunger might be "nothing" in comparison with Mary's emotional struggle is no sooner entertained than dismissed as unfeeling; Mary's "heart upbraid[s] her the next minute" and she retrieves food and "retrace[s] her steps" to give it to the boy $(M B, 202)$. A page later, though, Mary seems again dismissive of hunger as relatively insignificant, longing for "those days when hunger had been to her (as to the little stranger she had that evening relieved) something to be thought about, and mourned over" $(M B, 203)$. Such a dismissal might seem like part of a textual relocation of value from the lives of the hungry to the life of conjugal love - and the novel is doing this on one level—but the dismissal is also crucially part of Mary's misreading of the murder. ${ }^{44}$ Still thinking at this point that "she had been the cause" $(M B, 206)$, Mary too readily believes in the explanatory power of romantic love and does not make any connection between the hunger of this child and the hunger of her brother whose death so profoundly shaped her father's attitude towards the employers. But this connection is available to us. Even as the food plot seems to recede from the story, Gaskell draws attention to its traces.

Contrary to Poovey's argument that, in the end, any “competing plots have been absorbed into the marriage plot" $(147),{ }^{45}$ the novel's ending amplifies the traces of the

${ }^{43}$ Poovey, Making a Social Body, 152.

${ }^{44}$ My brief reading of this scene in The Food Plot underestimates its complexity, describing it as a straightforward shift from the food plot to the romance plot (45).

${ }^{45}$ Poovey, Making a Social Body, 147. Along with Mary Barton's domestic narrative, Poovey identifies strains of tragedy, farce, "the possibility of a sentimental story," the threat of "a gothic emphasis" (146), and the "promis[e]" of "a murder mystery" (147). Poovey's discussion here draws upon and acknowledges (214-15, n. 10) Catherine Gallagher's analysis of Mary Barton's "formal eclecticism" (Gallagher, Industrial Reformation, 67). For Gallagher, this eclecticism is due to a contradictory "tragic vision" 
food plot. After the trial is over and Jem is cleared of the murder, the dying John Barton says, 'I think one time I could e'en have loved the masters if they'd ha' letten me; that was in my Gospel-days, afore my child died o'hunger" $(M B, 321)$. The specter of the starved child not only reappears near the end but also haunts the well-fed child that we glimpse on the novel's final page, when Mary sings to her son: "Clap hands, daddy comes,/With his pocket full of plums,/And a cake for Johnnie" $(M B, 339)$. Johnnie is Mary and Jem's child: the emblem of the marriage plot's narrative resolution and promise of futurity. But while the well-fed child provides a trans-generation resolution to the narrative of John Barton and his starved child, the rhyme suggests that this resolution and its futurity are finally contingent on there being enough to eat and thus highlights the thin line between a child being a symbol of the future and becoming a Malthusian figure of surplus appetite. Ultimately, Mary Barton's marriage plot, in its very triumph, reveals its inextricability from the food plot.

\section{Conclusion: Rematerializing Appetite}

In closing, I want to return briefly to North and South, the novel from which I drew the pear scene that began this essay. While that scene shows food, eating, and appetite at their most subordinate, it constitutes part of Gaskell's rigorous rethinking of the role of eating in fiction; occurring at this early point in the novel, the scene displays a treatment of food and eating that the novel will turn away from. Later in the narrative, once her family has relocated to Milton, Margaret Hale visits the working-class Bessy Higgins before attending a dinner party at the family home of John Thornton, the mill

(75) that Gaskell "seeks refuge from ... in other narrative forms" (67) and ultimately abandons "in the novel's second half" (75). 
owner who Margaret will eventually marry. Discussing a strike, Bessy says, "Food is high, - and they [the strikers] mun have food for their childer, I reckon. Suppose Thorntons sent 'em their dinner out, - th' same money, spent on potatoes and meal, would keep many a crying babby quiet, and hush up its mother's heart for a bit!" to which Margaret replies: “Don’t speak so! . . Y You'll make me feel wicked and guilty in going to this dinner" (NS, 149). This exchange not only depicts the discrepant eating experiences of the working and middle classes but also puts pressure on the very technique of making meals set scenes in fiction that the novel deploys. Before this exchange, for Margaret the Thorntons' dinner party presents the prospect of a social space, and it is crucially a space that will help set Margaret on the path to marriage through her increasing acquaintanceship with John. But the exchange between Margaret and Bessie explicitly draws attention to the material ground of this social space as one that is not readily available to the working classes and even suggests that such material might be more effectively repurposed and redistributed as cheap food for "many" a crying baby. One space of novelistic life and futurity - that which advances the romance plot of the protagonist — is held up against another — that of the hungry children of a larger population. Schor has argued that North and South reveals a critical "concern with language" and novelistic "form." the kind of scene that allows a novel to arrive at its ultimate conjugal destination now emerges as an injustice that is simultaneously social and formal.

This critique is enabled partly by Gaskell's shift in emphasis across her two great industrial novels. Mary Barton focuses on working-class characters while North and

\footnotetext{
${ }^{46}$ Schor, Scheherazade, 140, 144; italics in original.
} 
South focuses more on middle-class characters and their interactions with the working classes. While this shift might seem like a retreat, it invites a movement from sympathizing with the working poor and bearing witness to their hunger towards an attempt at understanding not just the systemic imbalances between the middle and the working classes but also how the very modes of paying attention at work in middle-class reading and writing habits are complicit in such imbalances and contribute to the marginalization of appetite and working-class food plots. Another way that North and South develops this critique is through challenging the figurative use of appetite. While Margaret is on a later visit to the Thorntons' house, a crowd of strikers approach the house, and we get two different descriptions of the crowd: one which uses appetite figuratively and a second that uses appetite as cause. When the strikers see John Thornton, they "set up a yell" described as follows: "to call it not human is nothing, - it was as the demoniac desire of some terrible wild beast for the food that is withheld from his ravening" $(N S, 175)$. While it is difficult to tell whether this description belongs to the third person narrator alone or is focalized through Thornton's perspective, paragraphs later, we get another description of the crowd that is clearly filtered through Margaret's point of view:

Many in the crowd were mere boys; cruel and thoughtless, - cruel because they were thoughtless; some were men, gaunt as wolves, and mad for prey. She knew how it was; they were like Boucher, - with starving children at home - relying on ultimate success in their efforts to get higher wages, and enraged beyond measure at discovering that Irishmen were to be brought in to rob their little ones of bread. 
Margaret knew it all; she read it in Boucher's face, forlornly desperate and livid with rage. $(N S, 176)$

The repetition of hungry animal similes creates a shift from the deliberately dehumanizing description of the working-class crowd as being like a hungry animal to a description that sees the apparently animalistic appearance of the crowd as motivated by actual hunger and the rational need to end it. By putting the two descriptions so close together, Gaskell indicts the figurative use of appetite as a way of writing out and naturalizing material appetite and its consequences. The fact that Margaret's knowledge of the hunger that motivates the crowd comes to her through "reading" Boucher's face charges not only writing but also reading with the responsibility of moving beyond the figurative roles of appetite in order to recognize its materiality.

Gaskell's quest to bring such materiality out of the margins shapes the ending of North and South. The novel's industrial plot focusing on the relationship between workers and employers is resolved partly through mill owner and love interest, John Thornton, helping his workers to set up a cooperative dinner scheme involving good quality food bought wholesale and batch cooked to keep prices down. As Rosemarie Bodenheimer argues, the scheme "bridges the gaps the novel has brought into view": "It obliterates Thornton's earlier distinction between his men as workers and as human beings and allows for their independence from his management in the running of the dining room. ${ }^{27}$ Of course, in conjunction with such social reconciliation the scheme is crucially designed to mitigate the material conditions that plague the workers. The strike that forms the novel's centerpiece is prompted, after all, by "the price o'meat" and the

\footnotetext{
${ }^{47}$ Bodenheimer, Politics of Story, 58, 59.
} 
"hunger" $(N S, 150)$ that results from the discrepancy between working-class wages and food prices. When trade starts to go badly for John, he fears that he will have to give up his business and these sorts of schemes. Margaret, however, inherits a fortune, and her union with John means that he can afford to carry on his ventures.

The difference in the endings of Mary Barton and North and South gives us a measure of how, over the course of her industrial fiction, Elizabeth Gaskell developed her challenge to reading and writing practices that obscure the materiality of food, eating, and appetite. Where Gaskell's first novel critiques and undermines the form that it relies on, the later novel tries to envision a new form. Mary Barton at once enacts and interrogates a shift from a food plot centering on John Barton to Mary's romance plot, with the question of food and eating reemerging at the end, unsettling the novel's resolution with the specter of appetite. North and South explicitly unites the food plot and the marriage plot, re-imagining novelistic form as something that must be held accountable for the appetites that it so often writes out. If Mary Barton finally presents appetite as the evictee that never really leaves the house of fiction, North and South is eager to discuss shared ownership. While the biopolitical unevenness between appetite and sexuality would remain crucial to the framework of the nineteenth-century British novel, Elizabeth Gaskell, of all Victorian novelists, comes closest to achieving a moment of precarious balance, where the vision of life as something with an endless need to eat sits together with the vision of life as something with a future. 


\section{BIBLIOGRAPHY}

Agamben, Giorgio. Homo Sacer: Sovereign Power and Bare Life. Trans. Daniel HellerRoazen. Stanford: Stanford University Press, 1998.

Armstrong, Nancy. Desire and Domestic Fiction: A Political History of the Novel. New York: Oxford University Press, 1987.

Bodenheimer, Rosemarie. The Politics of Story in Victorian Social Fiction. Ithaca: Cornell University Press, 1988.

Bourdieu, Pierre. Distinction: A Social Critique of the Judgment of Taste. Trans. Richard Nice. Cambridge: Harvard University Press, 1984.

Cozzi, Annette. The Discourses of Food in Nineteenth-Century British Fiction. New York: Palgrave, 2010.

De Boever, Arne. Narrative Care: Biopolitics and the Novel. New York: Bloomsbury, 2013.

Edelman, Lee. No Future: Queer Theory and the Death Drive. Durham: Duke University Press, 2004.

Ellmann, Maud. The Hunger Artists: Starving, Writing, and Imprisonment. Cambridge: Harvard University Press, 1993.

Fleissner, Jennifer L. “Henry James’s Art of Eating.” ELH 75.1 (Spring 2008): 27-62.

Foucault, Michel. "Society Must Be Defended": Lectures at the Collège de France, 1975-76. Trans. David Macey. London: Penguin, 2004.

---. The History of Sexuality. Trans. Robert Hurley. Vol. 1. New York: Vintage, 1990.

Freedgood, Elaine. The Ideas in Things: Fugitive Meaning in the Victorian Novel. Chicago: University of Chicago Press, 2006. 
Gallagher, Catherine. The Body Economic: Life, Death, and Sensation in Political Economy and the Victorian Novel. Princeton: Princeton University Press, 2006.

---. The Industrial Reformation of English Fiction: Social Discourse and Narrative Form, 1832-1867. Chicago: University of Chicago Press, 1985.

Gallagher, Catherine, and Stephen Greenblatt. Practicing New Historicism. Chicago: University of Chicago Press, 2000.

Gaskell, Elizabeth. Mary Barton: A Tale of Manchester Life. Ed. Thomas Recchio. New York: Norton, 2008.

---. North and South. Ed. Patricia Ingham. London: Penguin, 1995.

Gigante, Denise. Taste: A Literary History. New Haven: Yale University Press, 2005.

Grossman, Jonathan H. The Art of Alibi: English Law Courts and the Novel. Baltimore: Johns Hopkins University Press, 2002.

Guy, Josephine M. The Victorian Social-Problem Novel: The Market, the Individual, and Communal Life. Basingstoke: Macmillan, 1996.

Hyman, Gwen. Making a Man: Gentlemanly Appetites in the Nineteenth-Century British Novel. Athens: Ohio University Press, 2009.

Kant, Immanuel. Anthropology from a Pragmatic Point of View. Ed. Robert B. Louden.

Trans. Robert B. Louden. Cambridge: Cambridge University Press, 2006.

Ketabgian, Tamara The Lives of Machines: The Industrial Imaginary in Victorian Literature and Culture. Ann Arbor: University of Michigan Press, 2011. Kingsley, Charles. Review of Mary Barton by Elizabeth Gaskell. Frazer's Magazine 39 (April 1849): 428-32. Gaskell, Mary Barton 380-82. 
Korsmeyer, Carolyn. Making Sense of Taste: Food and Philosophy. Ithaca: Cornell University Press, 1999.

Lee, Michael Parrish. The Food Plot in the Nineteenth-Century British Novel. London: Palgrave, 2016.

---. "The Nothing in the Novel: Jane Austen and the Food Plot." Novel 45.3 (Fall 2012): $368-88$.

Lesjak, Carolyn. Working Fictions: A Genealogy of the Victorian Novel. Durham: Duke University Press, 2006.

Levine, Caroline. Forms: Whole, Rhythm, Hierarchy, Network. Princeton: Princeton University Press, 2015.

Lukács, Georg. The Theory of the Novel: A Historico-Philosophical Essay on the Forms of Great Epic Literature. Trans. Anna Bostock. London: Merlin, 1971.

Lynch, Deidre Shauna. The Economy of Character: Novels, Market Culture, and the Business of Inner Meaning. Chicago: University of Chicago Press, 1998.

Macpherson, Sandra. Harm's Way: Tragic Responsibility and the Novel Form. Baltimore: Johns Hopkins University Press, 2010.

Malthus, Thomas Robert. An Essay on the Principle of Population. Ed. Geoffrey Gilbert. Oxford: Oxford University Press, 2008.

Matz, Aaron. "Hardy and the Vanity of Procreation." Victorian Studies 57.1 (Autumn 2014): 7-32.

Melville, Peter. Romantic Hospitality and the Resistance to Accommodation. Waterloo, Canada: Wilfrid Laurier University Press, 2007. 
Michie, Elsie B. The Vulgar Question of Money: Heiresses, Materialism, and the Novel of Manners from Jane Austen to Henry James. Baltimore: Johns Hopkins University Press, 2011.

Nord, Deborah Epstein. Walking the Victorian Streets: Women, Representation, and the City. Ithaca: Cornell University Press, 1995.

Otter, Chris. "The Vital City: Public Analysis, Dairies and Slaughterhouses in Nineteenth-Century Britain.” cultural geographies 13.4 (Oct. 2006): 517-537.

Poovey, Mary. Making a Social Body: British Cultural Formation, 1830-1864. Chicago: University of Chicago Press, 1995.

Rancière, Jacques. The Politics of Literature. Trans. Julie Rose. Cambridge: Polity Press, 2011.

Recchio, Thomas. "Melodrama and the Production of Affective Knowledge in Mary Barton." Studies in the Novel 43.3 (Fall 2011): 289-305.

Schaffer, Talia. Romance's Rival: Familiar Marriage in Victorian Fiction. Oxford: Oxford University Press, 2016.

Scholl, Lesa. Hunger Movements in Early Victorian Literature. London: Routledge, 2016.

Schor, Hilary M. Scheherazade in the Marketplace: Elizabeth Gaskell and the Victorian Novel. New York: Oxford University Press, 1992.

Sedgwick, Eve Kosofsky, and Adam Frank. "Shame in the Cybernetic Fold: Reading Silvan Tomkins.” Sedgwick, Eve Kosofsky. Touching Feeling: Affect, Pedagogy, Performativity. Durham: Duke University Press, 2003. 93-121. 
Steinlight, Emily. “Dickens’s 'Supernumeraries' and the Biopolitical Imagination of Victorian Fiction." Novel 43.2 (Summer 2010): 227-50.

Surridge, Lisa. "Working-Class Masculinities in Mary Barton." Victorian Literature and Culture 28.2 (Sept. 2000): 331-43.

Vanden Bossche, Chris R. Reform Acts: Chartism, Social Agency, and the Victorian Novel, 1832-1867. Baltimore: Johns Hopkins University Press, 2014.

Vernon, James. Hunger: A Modern History. Cambridge: Belknap Press of Harvard University Press, 2007.

Watt, Ian. The Rise of the Novel: Studies in Defoe, Richardson and Fielding. London: Chatto and Windus, 1957.

Williams, Raymond. Culture and Society, 1780-1950. Nottingham: Spokesman, 2013.

Woloch, Alex. The One vs. the Many: Minor Characters and the Space of the Protagonist in the Novel. Princeton: Princeton University Press, 2003.

Zlotnick, Susan. Women, Writing, and the Industrial Revolution. Baltimore: Johns Hopkins University Press, 1998. 